\title{
The Right for Rights:
}

The Lawful and the Lawless in India

\section{Raminder Kaur}

University of Sussex

\section{Chapter for Human Rights in India, ed. Satvinder Juss}

\section{We have been here [in Trichy Women's Prison] for over a month. We get} charged with new cases every time we are taken to the Court. It is only after being part of the [anti-nuclear] struggle that we realized that trying to establish one's right to live as one wishes, pursuing traditional livelihoods and also questioning activities that are being implemented without consulting the people is equivalent to crime and sedition (Sundari 2012). ${ }^{1}$

At the Press Club of India in New Delhi, Amnesty International launched its 2006 report among a room full of journalists, activists and scholars. It was concluded for the first time that India and China's rapid development has become another progenitor of human rights abuses. As the report reads for the two countries: 'Economic development did not prioritlze realization of economic, social and cultural rights'.2

In comparison to China, India is renowned as the 'world's largest democracy'. ${ }^{3}$ However, the juggernaut of neoliberal policies from the 1990s, 
increased trade with multi/transnational companies and attendant large-scale industrial constructions came with the striking abrogation of citizens' rights and consultancy on development projects. ${ }^{4}$ It heralded an era in which the government along with the growing middle classes embraced a globalised consumer culture for which more and more electricity was the order of the day. ${ }^{5}$ As they consumed, they veered more towards a 'pragmatic realism', where Indian officials formed relationships between superpowers like the US, Russia and China out of neoliberal necessity.

Nuclear power as an energy option was catalysed by the India-US civilian nuclear agreement (2005) and the subsequent waiver by the now 48 member countries of the Nuclear Suppliers Group in 2008. The waiver is despite the fact that India is not a signatory to the Nuclear non-Proliferation Treaty (1970), but with the condition that civilian nuclear reactors be open to inspection by the regulatory body, the International Atomic Energy Agency. More nuclear plants were planned for the subcontinent with ambitions to increase hundredfold their power contribution to the country's electricity needs (Ramana 2013: 279-292).

Simultaneously, as India sought to empower itself, insurgency rocketed. To add to the upheavals in Kashmir, Punjab and the north eastern states, the Indian government declared its support to US-led forces against the Islamic militant 'axis of evil' in the wake of the attacks on the twin towers of the World Trade Centres in September 2001. This 'War against Terror' led to a trenchant climate of terror that resulted in a strident securitised political culture (Masco 2014). Against this backdrop, any activist or environmentalist group denouncing state-backed industrial developments became tainted with the same brush as threatening national security (see Futrell and Brents 2003, Dunlap 2019). 
To intimidate individuals and quash environmentalist movements, there was a retrenchment of colonial legislation, where state authorities prohibited assembly as stipulated in Section 144 of the Code of Criminal Procedure (1973), and made allegations of sedition' and 'waging, or attempting to wage war, or abetting waging of war against the government of India' with recourse to clauses such as Sections 124A and 121. Such legislative mechanisms that were used to give the upper hand to political, industrial and corporate elites came up against a rise of environmental awareness in league with a culture of entitlement for project-affected people that Sanjay Ruparellia has described as 'the new rights agenda' (2013: 569). A lack of public consultation, compensation and the prospect of displacement from home and habitat rang as loud as threats to their life and livelihoods were they to stay (see Flam 1994, Srikant 2009: 3).

Mechanisms for public consultation and information in the public interest along with those framed by India's democratic constitution were mobilised to these ends by campaigners. The former included laws such as the Environment Impact Assessment (EIA) Notification in 1994 that is under the umbrella of the Environment (Protection) Act of 1986, and the Right to information Act (2005) for vital information from public authorities. The latter, often cited as 'the supreme law of India', pertained to fundamental rights of the Indian citizen including the right to peaceful dissent and to live in a healthy environment. Specifically, Article 19(1)a of the Constitution of India refers to 'the right to freedom of speech and expression' and 19(1)b to assemble peacefully and without arms. Article 21 decrees 'no person shall be deprived of his life or personal liberty except according to procedure established by law' (Agarwal 2012: 205). This article in particular has been interpreted as an essential human 'right to life' including rights to water, a livelihood, health, education, 
and the right to a speedy trial. With Article 32, individuals could seek remedy for any violations of their fundamental rights (Rakshit 1999).

This is the volatile politico-legal field that marks people's lives in India with respect to large-scale developments. On numerous occasions, such rights enshrined in law turned out to be no more than a paper tiger to the mightier roar of the Indian nuclear tiger. The import and implementation of laws were disregarded or weakened by the greater force of the 'nuclear state' - a term used to refer to state-endorsed nuclear authorities such as the Department of Atomic Energy and the Nuclear Power Corporation of Indian Limited bulwarked by an increasingly intransigent and militarised police, surveillance and intelligence apparatus under the umbrella of national security. ${ }^{6}$ Recalling Carl Schmitt (1985 [1927]) and Robert Jungk, (1979), juridical norms and procedures of decision-making are held to ransom when it comes to exercising a decision on nuclear technologies, whether they be for weapons or power plants. This state of affairs stretches from local authorities all the way to the highest representative of law in the country, the Supreme Court of India, who in its call for experts to furnish evidence in any appeal against the nuclear authorities, has to rely upon officials, themselves employed or sponsored by government-backed authorities. Effectively, the nuclear enclave becomes the exception to law in the interests of the nation and its security (Kaur 2013).

A significant test case concerns the Kudankulam Nuclear Power Plant in the south Indian state of Tamil Nadu (Figure 1). An agreement for the plant was first made by the premiers Rajiv Gandhi and Mikhail Gorbachev in 1988 that were later shelved for a decade. It was revisited in the late 1990s by the then Indian Prime Minister, H. D. Deve Gowda, and the Russian President, Boris Yeltsin. Strapped by their own economic needs for nuclear trade, the Russian industry entered into 
another agreement to supply two standard high pressure VVER 1000 megawatt reactors with renewed arrangements that became connected to defence deals including the supply of T-90 tanks, SU-30 planes and the Admiral Gorshkov submarine (cited in Udayakumar 2004: 138). ${ }^{7}$ In the aftermath of India declaring itself a nuclear weapons state in 1998, a revised agreement was made along with repayments in dollars and spent fuel to be kept in India (Ramana 2013: 86-88). Signed by the right-wing Bharatiya Janata Party (BJP) leader, Atul Bihari Vajpayee, and the Russian President, Vladimir Putin, the pact was bought to life in November 2001, and construction of the nuclear plant began shortly after (Figure 2).

The Kudankulam case demonstrates the coordinated activities of campaigners who pursued processes of democracy that promise project-affected people a fair hearing, accountability and compensation. Their 'people's movement' had national and even transnational repercussions (Kaur 2012, 2019a). A few months after the Fukushima-Daiichi disaster in March 2011, a neighbouring village to the Kudankulam Nuclear Power Plant, Idinthakarai, became the 'epicentre' of an anti-nuclear movement as thousands gathered to support the People's Movement Against Nuclear Energy (PMANE, Figure 3). Prominent here was the role and commitment of women, of which Sundari whose quote opens this chapter is one leading voice in the peaceful protest of women against a nuclear power plant. $^{8}$

Peoples' anxieties about land acquisition, displacement, mandatory procedures in the construction of a nuclear power plant, radioactivity and the prospect of their future health and livelihood fuelled an anti-nuclear rage. Making firm connections between the state, security and oppression in the name of India's development, grassroots resistance swelled across the southern peninsula and beyond. They were inspired by Mohandas Karamchand Gandhi's ideas of village- 
based solidarity and non-violent civil disobedience for the people whose philosophical political legacy they adapted for the contemporary Tamil Nadu context (see Hardiman 2003). This phenomena permit a consideration of the politicised framing of 'people' as essentially a powerful collective voice against the state, and more specifically, against the nuclear authorities: people power against nuclear power (see Laclau 2005, Bidwai 2011, Kaur 2012).

In the context of a fast developing neo-liberal India, it has become more and more evident that the right to life, public consultation and information in the public interest, along with the freedom of expression and to dissent are being suppressed and/or diverted in the interests of supposedly 'higher goals' to do with national security and the modernist mantra of development. In this chapter, we consider how people's rights have been shaved and shred with a focus on the south Indian nuclear plant. Despite the often capricious and varied interpretations and enactments of principles embodied in law and regulations by the nuclear state, communications and coordination continued among anti-nuclear campaigners in quite open ways, protagonists often arguing that there was no need to hide anything for what they were doing with their peaceful forms of civil disobedience was perfectly legal. As one person put it, "Why should we worry about the state when it is us who are lawful, and they are lawless?' Activists set out to demonstrate how they, the people were in fact lawful and therefore the authentic enforcers of justice, while the nuclear state was lawless for deploying established 'law enforcement agencies' to aggressively push through its agenda paying short shrift to constitutional, legal and mandatory protocol.

After a brief account on the anti-nuclear struggle in south India culled from ethnographic fieldwork in the region since 2006 and an analysis of material available online, the workings of the inverted logics of the lawful and lawless will be 
demonstrated with respect to three main areas: first, the twists and turns to people's constitutional right to life; second, the shunting of rights to information about mandatory procedures for the construction of a nuclear power plant, and to public consultations and hearings for project-affected people; and third, the undermining of people's right to peacefully protest without the threat of punishment or detention. Unless they are a public spokesperson, the identities of my interlocutors have been anonymised accordingly.

\section{Cross Currents}

By the mid-2000s, two reactors at Kudankulam were under construction and scheduled to go critical in 2007 , a date that was perpetually postponed until, as it transpired, the first reactor was commissioned much later in July 2013 to be followed by the second reactor three years later. As with many other nuclear plant constructions, worries were expressed about radionuclide emissions released into the environment, the rise of the sea water temperature due to the discharge of water coolant that would disturb sea life and, as a consequence, further jeopardise fishermen's livelihoods. Exposure to the high background radiation along the south western Malabar coast in the neighbouring district to Tirunelveli where the nuclear plant is sited, is deemed to be 'higher than the world average value reported by UNSCEAR [United Nations Scientific Committee on the Effect of Atomic Radiation] (2000)' (Ajithra 2017: 33). Along with sandmining among the monazite-rich coastal sands (an alpha radiation emitter) in the coastal districts, it has predisposed the population to a high rate of genetic mutation and related diseases. Having nuclear reactors in the region added to their radiation burdens. 
People in the region felt that they were hinterland underdogs for power interests emerging in large cities to the north hand-in-hand with trans/multinational companies. Some likened the phenomena to a form of neo-colonialism where people's lives were oppressed and their rights abrogated as it was under the British colonial era. The writer and peace activist, Dr S.P. Udayakumar, described the phenomena as 'nucolonization (nuclear + colonization)'. ${ }^{9}$ At a meeting in 2006, he declared:

Government is dictatorial. Our enemy is very powerful. The nuke industry is very powerful. It is the enemy of our people. Many people are afraid to do anything against this department [the Department of Atomic Energy].

A leaflet from the local Conservation of Nature Trust in 2006 added:

The Russians may be happy over the pact as it will boost its dollar hungry economy with an inflow 360 crore [3.6 billion] of US dollars (Rs 173,000 crores) work as this is entrusted to 300 industrial units in Russia which will manufacture parts for the VVER-1000 Reactors. It is like manufacture of cloth in Manchester, England for India in the Pre-independent India [sic]. ${ }^{10}$

The inequities of colonial exploitation of India's resources were likened to the contemporary scenario where Russian technology was brought by India at exorbitant costs that were then borne financially and environmentally by the Indian government and by extension, Indian citizens. Indeed, it has been revealed that equipment for the commissioned reactors had not been adequately maintained (Ramana 2013: 8687; Bhawna 2016: 226-7). Nor, as it was learnt later, were they the ones that were originally planned. Rather, they were reputed to be substandard versions provided by Russian companies, Ziopodolk, Informtekh and Atommash, whose CEO's have 
been jailed for corruption for the sale of aged and defective Soviet era equipment (Padmanabhan et al 2013). People in peninsular India felt that they were to become the 'guinea pigs' to this outdated and untested technology (Vaid 2016: 108-148).

In a context where the Indian nation-state has prioritised economic and military growth, residents around the nuclear power plant have redressed the terms of development to make it more people-orientated and environment-friendly. Such perspectives provide a cutting critique of 'nuclear nationalism' (Bidwai and Vanaik 1998) that is entrenched in mainstream Indian political culture where the nuclear is heralded as a pre-eminent path for the postcolonial nation's sovereignty, defence and development (Abraham 1998). Activists tried to intercept this dominant discourse not by resisting it altogether but by de-linking the nuclear from the national. With this orientation, they were able to revere the national as a discursive script that values the power of the demos, the rights of the citizen, and encapsulates love and respect for their historical, cultural and environmental heritage. By effective delinking, they, were to a greater or lesser extent, able to circumvent accusations of being 'anti-national', 'anti-development', and try to fend of accusations of foreign infiltration and espionage.

Strategies to enable this reorientation included the revival of India's nonviolent freedom struggle that valorised the struggle as one for the 'people'. Other campaigns entailed the mobilising of striated conceptions of Indian and/or Tamil culture through a variety of practices and outlets to disseminate the dangers of the nuclear industries and the ills of high ionising radiation levels. A third approach included efforts to connect with wider everyday issues such as the universal life value of fresh water, and how tons of it are needed for a large power plant, a concern that spread to inland farming as well as fishing communities in their eco- 
nationalist campaigns. Fourth were tactical use of survey, statistics and science that was mobilised in a bid to create a parallel and locally informed knowledge base of 'citizen experts' with which to inform critical action and creative resistance through a variety of outlets including social media. Fifth were legal challenges in a form of 'judicial activism' as goes Alf Gunvald Nilsen's (2012) analysis of the Narmada Bachaho Andolan (NBA) campaign to ensure people displaced in the construction of the dam along the Narmada River in Gujarat and Maharashtra were properly rehabilitated and compensated. We will now consider some of the means by which critics tried to take the nuclear bull by the horns.

\section{Sublime Channels}

Anti-Kudankulam Nuclear Power Plant strategies from the 2000s showed an increasing arraignment in judicial activism. Notably, in 2002, people in the southern peninsular came together with the retired marine biologist $\mathrm{Dr}$ Samuel Lalmohan at the lead to start a court case under Article 32 of the Constitution of India for their fundamental right for life. It went to the Supreme Court but in a country where the average duration of a court case is five to ten years, the case was dismissed in a matter of weeks with the verdict:

There is an inordinate delay in filing the writ petition. Secondly, the question of setting up the power station is a matter of policy. There is no reason as to why this court should sit in appeal over the Governmental decision relating to a policy matter more so, when crores of rupees having been invested. This petition is dismissed with costs of Rs 1000 which shall be paid to the Supreme Court Legal Services Committee. ${ }^{11}$ 
Pointing out the delay of the petition and reminding them of the costly implementation of government policy made the appeal redundant. All in all, the case cost the complainants much more than Rs 1,000 , totalling about Rs 40,000 plus flights to and fro Delhi - by train, the journey would take three days, a time that many of those who worked could little afford. ${ }^{12}$

Subsequently, in a coordinated effort led by Udayakumar, a letter was sent to the Executive Director of the United Nations Environment Programme (UNEP) on 23 October, 2002. It declared:

The Indian Central Government is proceeding with the construction of the Kudankulam Nuclear power plant in spite of all the protests that has been made by numerous bodies and organisations. We have now decided to make a plea to your good self, having no other recourse [sic].

After a list of the main problems associated with the Kudankulam Nuclear Power Plant, the letter ends:

The Central Indian Government has arbitrarily carried out this project, without resorting to norms of Environmental Impact assessments, public hearings and against the public opinion. As political corruption is rampant in these regions they callously disregard adverse impact that will transpire as a result of carrying out this project. Finally, we believe, that with your good office having responsibility for the environment of the whole world, that you will be able to intervene on this monstrous project and make our area a safe haven to live in nuclear pollution free environment. [sic] 
A month later, a response arrived. The Regional Director and Representative for Asia and the Pacific remarked 'that this matter goes beyond the mandate of UNEP's activities in the region, and perhaps, it would be best if you were to consult the International Atomic Energy Agency (IAEA)'.

Knowing full well the futility of an approach to the IAEA whose raison d'être was indeed to promote the 'peaceful use' of nuclear power, an appeal was instead written to the Delhi-based National Human Rights Commission for the urgency of a public hearing, the need to issue a transparent Environmental Impact Assessment report for the initial proposal of two reactors as per India's 1994 EIA Act, and a summary of the hazards to people's health and the environment by a nuclear power plant.

The response received on 14 November 2005 was a point-by-point rebuttal. It declared that the project was first cleared in 1989 and therefore lies out of the Act's purview. It furnished select evidence from the Nuclear Power Corporation of India Limited (NPCIL) who are the public-private authority responsible for the Kudankulam construction and the Atomic Energy Regulatory Board (AERB), a regulatory body itself populated by people who serve the DAE. It concluded that the plants under construction will not pose any unacceptable risk to the plant personnel, public and the environment', emphasising that:

in an energy deficient country like India there is a need to produce electrical power by all available generation technologies, that is, hydel [hydro], thermal, nuclear or renewable energy sources. Nuclear power plants are environmentally benign with respect to carbon dioxide emission and therefore cause no global warming...It has been detailed that France has adopted 
nuclear power as their main source of energy supply and as of today more than $75 \%$ of the total power requirements of France are met by nuclear power. Likewise Japan, Korea, China, America, Russia and many other countries have adopted nuclear power as one of the significant energy sources for meeting their requirements.

In its reliance on somewhat questionable evidence as to the 'environmentally benign' nature of nuclear reactors, the letter asserted that the:

Cancer Research Institute, Thiruvananthapuram [Trivandrum] has undertaken in-depth study of effect of low level radiation on the population on the population in high natural background area of Kerala. The study revealed that the prevalent high natural radiation background does not contribute to any abnormal increase in cancer/early abortions and mental retardation... The Nuclear Power Plant like Tarapur Atomic Power Station, Madras Atomic Power Station have been operating in coastal areas for about thirty and twenty years respectively and fishermen have not observed any adverse effect on their catch. In view of the factual position detailed above, it has been concluded that the complaint does not warrant any consideration, being devoid of merits [sic]. ${ }^{13}$

The response concluded: 'In view of the facts and circumstances detailed above, report of Undersecretary, Department of Atomic Energy, Govt of India, is taken over the record and matter is closed' [sic].

One swing door after another had been shut upon the petitioners. The word of the highest court in the land had carried authority and nothing else could be done about it. It was an indication of a judicial catch-22: that Supreme Court judges do 
not have the scientific expertise to judge the matter at hand and therefore need to call upon nuclear experts, all of whom are directly or indirectly employed or sponsored by the Indian government. This verdict is then upheld by others. Even the National Human Rights Commission conferred more rights to 'electrical power' citing reports and studies that themselves had been conducted by state-supported organisations.

One local resident declared that: 'The DAE is misleading people with halftruths and non-truths'. He concurred that it is matters like this that underline the Indian government's reluctance to have any international oversight on human or people's rights:

The government claims that it is acting in the national interest, that people from other countries could not possibly understand the Indian situation, and that the nation does not need international human rights agencies.

He concurred that it is matters like this that underline the Indian government's reluctance to have an International Court for Human Rights in India. The government claims that it is in the national interest, people from other countries could not possibly understand the Indian situation, and that the nation does not need it. However, he elaborated that it permits the Indian government to act like 'a democratic dictatorship' against the will of its own people. In other words, it utilises the velvet language of democracy while exercising the iron fist of a dictatorship (Kaur 2019b). 
While recognising that the turn to nuclear power was partly due to the international consensus for nuclear power with George Bush Junior at the helm, people made comparisons with petitions against trans/multinational and state decisions for nuclear power stations in the US where the supreme weight of the US constitution, which also grants similar privileges to the one in India, held out against the interests of adverse corporate and state-backed decisions. Indeed, it was partly due to relatively lax regulations that US nuclear companies were so attracted to doing trade in India. The sobering realisation was that Indian lives were not considered worthy even by their country's own government. US citizens' rights record seemed enviable next to those of Indians even in these post-9/11 years of intensive surveillance and control (see Masco 2014).

\section{The Right to Know and be Heard}

In an unprecedented move in 2012, the Right to Information (RTI) Act (2005) was successfully used as part of a second appeal by south Indian campaigners with Udayakumar at the helm to obtain information in the public interest from nuclear authorities. With a litany of acts such as the Atomic Energy Act (1962 with later amendments) and, with its imbrication in national security, the Official Secrets Act (1923), the National Security Act (1980), along with other exemptions, the nuclear authorities had previously held themselves strictly off-limits to the public.

The eventual release of some information was in direct response to the Central Information Commission's order in April 2012 to provide documents that are relevant to public safety concerns regarding the two reactors at the Kudankulam

Nuclear Power Plant. Even though Sections 8(1)(a) and (d) of the RTI Act exempt 
any information that might compromise the 'security, strategic and scientific interests of the State' or 'commercial confidence' of the parties involved, no information was provided to support the NPCIL's claims at the hearing. ${ }^{14}$ Furthermore, as the appellant, Udayakumar pointed out, 'reports of the same nature were classified as public documents in countries such as USA, UK and Canada in order to ensure public debate'. ${ }^{15}$ The Commission permitted the second appeal concluding that:

Where world wide, site evaluation and safety analysis reports of nuclear power plants and installations are being put in public domain to elicit public views, India can have no reason to treat its Citizens differently [sic]. ${ }^{16}$

Subsequently, the NPCIL released one of the two requested reports, the Site Evaluation Report (SER), on 18 May 2012. The NPCIL denied the public release of the Safety Analysis Report stating that "is a 'third party document' and therefore, without the prior consent of the third party, the same cannot be shared with anyone." [sic] The third party is Atomstroyexport and Atomenergoproekt (AEP), under the state corporation, Rosatom, in Russia.

Even while the undated and barely legible twelve page SER that was released obscures much, it contains some startling information. ${ }^{17}$ It demonstrates the backtracking of official declarations that water from the Pechiparai Dam would not be redirected to the Kudankulam Nuclear Power Plant, which was the official declaration by the NPCIL. The report states:

In order to enhance additional reliability for water supply, which is essential for functioning of various safety systems of the reactor, intake well at Pechiparai Dam should be provided at lower elevation than the minimum draw-down 
level of the reservoir. However, it should be ensured by proper management of water distribution that the water level is maintained above this minimum level.

Two pipelines had already been laid from the tail end of the Kuzhithurai Tamirabharani River along the Kanyakumari district coast and from a location about 5 kilometres away from the Pechiparai Dam through Nagercoil town. The Tamil Nadu state government had also recently allotted nearly Rs. 5 crore $(50,000,000)$ to desilt the dam and maintain it. Regional inhabitants were naturally worried about what this might mean to their own supplies of water. However, for fear of further local retaliation, the necessary water for the plant has not to date been drawn from the Pechiparai dam. The Kudankulam nuclear project instead relies upon costly desalination plants on the site that are nowhere mentioned in the released report.

Elsewhere, information on hydrology, geology, oceanography and seismology is reported in a table and without in-depth analysis. Issues such as the tsunami in an area that was ravaged by the 2004 disaster are explained away by saying "not significant.' As far as the seismo-tectonic environment is concerned, the report asserts that 'No active fault within $5 \mathrm{~km}$. Site is seismic zone II as per IS-1893; 1984 .' Other issues such as karst in the area, the slumps in the sea along with the earthquakes in the Indian Ocean as raised by independent experts such as V.T. Padmanabhan, Dr Ramesh and Dr. Pugazhendi are not raised at all. ${ }^{18}$

The report also reveals that the liquid waste from the Kudankulam Nuclear Power Plant will 'be diluted' and 'discharged into the sea' which added to the consternation of nearby fishing communities. On evacuation routes in case of a nuclear emergency, the report merely states: 
3 routes exist for possible evacuation. Schools and other public buildings exist for adequate temporary shelter, Nagercoil (30km), Tirunelveli (100km), and Tuticorin $(100 \mathrm{~km})$ can provide communication, medical facilities and administrative support.

There are no further details about the routes, the condition of roads or the preparedness of relief centres.

Most astounding is the use of the name, 'Soviet Union', instead of Russia at several points throughout the report. It was most probably from before the dissolution of the former USSR in 1991 when plans for the Kudankulam Nuclear Power Plant were first developed to be put on hold until 2002 when construction began.

In a response to the release of the report, Udayakumar concluded that the report was outdated and could not be taken seriously:

There is hardly any mention of desalinations plants, the transportation of the nuclear waste and other crucial issues. To sum up, this SER reads like a practical joke being played upon the innocent people of southern Tamil Nadu and southern Kerala. The PMANE rejects this so called SER and demands the NPCIL to share the real, complete and updated Site Evaluation Report with the people of India along with the Safety Analysis Report as per the orders of the Central Information Commission. ${ }^{19}$

Despite increasing pressure to reveal accurate and up-to-date safety reports, the NPCIL ignored any further requests. 
Public hearings along with the public circulation of an Environmental Impact Assessment $(E I A)$ report had been made mandatory for large-scale development projects by the EIA Notification in 1994. However, when the NPCIL held public hearings, they were done in a rash and 'secretive' manner so as not all members of the public could attend, and any appeals at the hearing were not fully acknowledged in their reports (Ramana and Rao 2008, Kaur 2013). ${ }^{20}$ The nuclear authorities had proceeded without proper consultation with the public who would be affected by the

plant. With the backing of the legislature, surveillance and recourse to sanctioned violence (Weber 2015), the Indian nuclear state with its especial mooring in central government has conducted environmental enquiries for the construction of further reactors primarily for itself, and this so in only a summary fashion. Legislative routes against the Kudankulam Nuclear Power Plant were proving to be intransigent and the NPCIL's public engagements appeared almost farcical were it not for their ability to push their agenda through with the help of intelligence bureaus, the police and paramilitary units.

\section{The Right to Peaceful Protest}

Gathering people to rally to the cause was an important part in the effort to assert people power against nuclear power. As in the struggle against the colonial machinery of yore, recourse was made to civil disobedience. But even with respect to peaceful dissent, authorities reacted by trying to shunt, curtail, ban and enact violence against those that defied and mobilised against the nuclear power plant.

Among PMANE acts of civil disobedience, a 'fast until death' in August 2011 led to the stalling of the construction of the nuclear plant for half a year with the 
short-term support of the Tamil Nadu Chief Minister, Jayaraman Jayalalithaa, as she herself played the hand of the prime minister, Manmohan Singh's central government. But this tenuous support from the Tamil Nadu government was shortlived. In March 2012, PMANE had organised a two-day national cultural programme. It involved many presenters and supporters travelling to Idinthakarai to come together in solidarity. When the crowds had dissipated after the programme, the police racked up their surveillance of the village. On the evening after the national event, a police car drove into the village to check at the parish whether there were any 'outsiders' in the village. Some had overstayed after the cultural programme but, on learning about the visit of the police, they decided to leave that night.

Earlier in the day, the personal assistant to the Tirunelveli's District Collector requested that Udayakumar and Father Jayakumar meet him in his office the next morning. This was followed up by two calls from the Collector himself, Dr. R. Selvaraj. Something seemed to be brewing. People in Idinthakarai were troubled, expecting something, perhaps a restart of the reactor construction. But how events transpired still caught them by a combination of surprise and shock.

The following day, roughly 6,000 armed police and paramilitary units were swiftly relocated to Kudankulam shortly after a local by-election. ${ }^{21}$ They blocked off the main road into Idinthakarai with barriers and armoured vehicles. In the process, they stopped all bus services and supplies of water, food, milk and fuel that coastal residents relied upon for their daily needs. The state government imposed Section 144 that prohibited any kind of large meeting and entry or exit out of the village. They also arrested about a thousand people across the state, some of whom were charged for sedition and inciting communal violence, and later released. ${ }^{22}$ Residents complained. But the police stated that if the blockade was to be lifted, PMANE 
convenors, Udayakumar and former priest and environmentalist, M. Pushparayan, had to be first handed over. People in Idinthakarai responded with a chorus of rebuttals, saying that they should arrest each and every one of them, if sedition is to be the charge. Udayakumar recalled this series of events after the phone calls in an open letter:

A warning bell rang in my mind and I told my friends that we were all going to be arrested. My intuition proved to be right; some 200 of our friends from Koodankulam, Koottapuli, Chettikulam and Erode were arrested. Rayan and I and 13 others embarked on an indefinite hunger strike demanding our friends' immediate and unconditional release.

The Superintendent of Police, Mr. Vijayendra Bidari, called me on my mobile on March 19th evening and asked me to surrender. With him still on the phone, I asked the thousands of people who had gathered there for their permission to surrender and they all shouted down the idea. I asked the SP [Superintendent of Police] to send enough vehicles and two officers with the arrest warrants so that we all would get arrested en masse. He did not like that idea and hung up by saying, "This is the last time I speak to you." We used to speak to each other quite often as I got his oral permission for all our rallies, campaigns and public meetings. ${ }^{23}$

Udayakumar's appeal to the people that he should go outside was met with emotional scenes of hugs and tears, as people held tightly on to him, not wishing to let him go. The activist fisher woman, Tamilarasi, reflected on her lament: 
His words seemed to me like a farewell. I just could not take it. I felt that someone has departed forever. I cried like I have not in years. And without me knowing I ran up the steps to the stage and embraced him, my dear brother. ${ }^{24}$ A solidarity visit by Arvind Kejriwal, the leader of the Aam Aadmi Party sealed the collective mood, and Udayakumar and Pushparayan decided to not surrender to the police. ${ }^{25}$ Instead, with renewed vigour they intensified their agitation.

As protests grew in and outside the village from 2012, so did criminal charges against PMANE. Acts of civil disobedience were read as acts of legal disobedience. Allegations in First Information Reports (FIR) piled up on top of named individuals invariably including Udayakumar and Pushparayan - along with a couple of thousand or more unspecified others. Reportedly, nearly 9,000 had been accused of 'sedition' and 'waging war against the state', allegations that carry with it the prospect of life sentence or a death penalty. ${ }^{26}$ Typically, a few names would be mentioned in any charge with the added number of $2-4,000$ to add to the list of named individuals in strategies of creating a fear psychosis. ${ }^{27}$ The exact figures have vacillated along with the prevarications of officials and some were subsequently dropped after campaigners appealed to the Supreme Court. ${ }^{28}$ In a desperate attempt to contain the protests, the charges constitute the most ever criminal allegations from one station in the history of modern India.

Even though their rate of proliferation made the allegations seem almost preposterous, they were not to be taken lightly. Along with 'sedition' and 'waging war against the state', there was also recourse to related laws such as Sections 147 with respect to rioting, Section 148 in relation to rioting with deadly weapon, 353 implying 'assault or criminal force to deter public servant from discharge of his duty', 121(A) referring to 'a conspiracy to overawe, by means of criminal force or the show of 
criminal force, the central government or any state government', 395 with respect to dacoity, 307 in relation to the attempt to murder, r/w 149 IPC on unlawful assembly and Section 3 of TNPPDL Act (Tamil Nadu Public Property Damage Act) with respect to causing damage to public property, 431 with allegations of damaging road, bridge, river, channel, and so forth. Children were not left without charges: they were registered under Sections 147, 148, 353, 121, 124, 129(b) with respect to 'sings, recites or utters any obscene song, ballad or words, in or near any public place', and curiously, 307 IPC r/w 149 IOC and Section 4 of Endangered Species Act and Section 3 of TNPPDL Act. (sic, cited in Senthalir 2012: 14). The reports were either fabricated or exaggerated, and in their repeated iterations, created a political theatre of the absurd. ${ }^{29}$

Udayakumar called the state's official bluff. He responded by saying that if sedition was the issue, then they had been in meetings with the 'Prime Minister of India, the Chief Minister of Tamil Nadu, the Tirunelveli District Collector, the Tirunelveli Superintendent of Police (SP) and many other officials' who too should also be considered under these charges.

Udayakumar made parallels with their oppression and the Emergency, a two year period of systematic rights violations from 1975 under Indira Gandhi's Congress government. Along with others, he overturned state accusations of them as 'seditious' and turned the accusatory finger to those officials in state power:

remember the 'Emergency' and MISA (Maintenance of Internal Security Act) days. Yes, there is a silent emergency prevailing in India today. The State that accuses us of waging war against it is indeed waging a war against its own people. Also we have to ask what is seditious today in India. The Manmohan Singh government has scores of ministers who are accused of serious 
corruption and fraudulence charges but it is the common people like us who struggle for the safety and betterment of our people stand accused of sedition. ${ }^{30}$

In this 'silent emergency' from March 2012, more than three hundred people mainly women embarked upon another indefinite hunger strike demanding the release of protestors that had been imprisoned across Tamil Nadu. They also reiterated their demands for an independent environmental study around the Kudankulam Nuclear Power Plant, the public release of an Inter-Governmental Agreement signed by the Indian and Russian governments on liability in February 2008, and the need to conduct mandatory safety and evacuation drills in a 30 kilometre radius of the plant. ${ }^{31}$ All hunger strikes from August 2011 were called off with meetings with officials that, as with most other promises, proved to be inconsequential in the long run. This last hunger strike was simply ignored by officials. One of Mohandas Karamchand Gandhi's greatest weapon of sacrificing the body in view of the welfare of the community and nation was thrown on the pyre of peaceful politics.

While this effective siege and stand-off was ongoing in and around Idinthakarai, violence was also enacted upon anything or anyone associated with PMANE. Henchmen believed to be connected to the local right-wing group, Hindu Munnani and Congress, took to damaging the properties of the lead spokesperson with two attacks on the SACCER Matriculation School that Udayakumar's wife, Meera, on the outskirts of Nagercoi. This came with a systematic attempt to intimidate them through threats, rumours and other measures to undermine the school as a 'den for terrorism' in order to put parents off from sending their children to the school. Despite formal complaints to the Rajakkamangalam Police Station officers, the Deputy Superintendent of Police in Kanyakumari town and to the 
Superintendent of Police in Kanyakumari District including also a letter to the chief minister, no one was taken to task. ${ }^{32}$ The silence and inaction pointed to a state-wide complicity that stretched between official and not-so-official elements (Kaur 2020).

\section{The Lawless State vs Lawful Nation}

Despite stipulations that frame citizen's rights to a healthy environment, information, public consultation, and peaceful dissent, various ruses are enacted by state-backed authorities to ensure that such legitimate avenues are curtailed. People's rights to life are simply ignored or diminished as we saw with the first series of appeals above. Their rights to information about nuclear developments are denied or short-changed as we saw with the outdated and cursory Site Evaluation Report that was eventually released in 2012. With regard to the mandatory EIA report and public hearing, consultations are planned with a preordained, circumscribed and docile public known to support the nuclear plans in mind. People's rights to peaceful dissent are violently trampled upon as we saw with the nuclear state's response to peaceful acts of civil disobedience, a situation that was not unlike the colonial era or earlier periods of oppression under Indira Gandhi's Emergency rule.

A democracy descended quite rapidly into a demockery. The Kudankulam struggle vividly illustrates how the nuclear state indicates a propensity for violence while deploying a selective and cursory rational-legal proceduralism that effectively make a mockery of the democratic constitution. In the process, the state is (re)produced as distant, hierarchical, capricious and unaccountable to the public. While the Indian judiciary aspires to do a stellar job, the lower courts are compromised by corruption and painfully slow processes. In the meantime, claimants who are detained suffer and fester in jail for months if not years. On the nuclear 
issue, the judiciary as a whole is in a circuitous stranglehold. All of them including the Supreme Court are hampered by the fact that they rely upon experts to furnish evidence where needed, who themselves are employed or sponsored by the nuclear state.

With the election of the Bharatiya Janata Party (BJP) in central government in 2014, measures against environmental and human rights organisations have seen a step-change with rising allegations of sedition and anti-nationalism. ${ }^{33}$ In 2017 alone, up to twenty thousand NGOs have been threatened for their 'anti-national' work in a crackdown on bank accounts under the Foreign Contribution Regulation Act (FCRA). ${ }^{34}$ This compared with around 4,000 cancellations of FCRA status after the revised FCRA Act was first implemented under the previous United Progressive Alliance government in 2011 for the stated reason of non-submission of annual returns within nine months of the end of the financial year. ${ }^{35}$ Even well-established organisations such as Greenpeace India have had their funding status revoked for about a year before court proceedings reversed the decision. This is one organisation that had raised awareness about environmental violations with the Kudankulam Nuclear Power Plant and, among their other work on health and environmental justice, they have been pulled up for 'prejudicially affecting public interest and economic interest'. ${ }^{36}$ Other NGOs have been put on a security watch for engaging in activities seen as inimical to the BJP agenda. ${ }^{37}$ Critics recognise that the crackdown is to expunge any movement that they do not approve of, and to shackle dissent and criticism in the country where the FCRA is being used as a 'tool of repression'. ${ }^{38}$ Others bring to attention the communalisation of allegations in what might be called 'Hindia'. It is true that the BJP government has not reproached 
Hindutva organisations such as the Rashtriya Sevak Sangh [RSS] who are held to be 'getting crores from Indians living in other countries' ${ }^{39}$

Nevertheless, with the support for the People's Movement Against Nuclear energy, the Kudankulam case remains a striking thorn in the Indian nuclear state. It is a memorable example of a multi-pronged movement that brought people from diverse backgrounds together on grounds of environment, health, livelihood and 'deep democracy' (Appadurai 2001) where expressed efforts were made to connect with other marginalised and large-scale development project affected people across the country. While campaigners nurtured visions about societies run on alternative energies, they did not seek to usurp extant structures of law and politics. Rather they sought to almost 'cleanse' the extant state, to pull it to task, so to speak, so that it did not prevaricate from values enshrined in the sublime umbrella of the Indian Constitution (see Hansen 2001) and related legislature on public transparency, consultation and mandatory procedures in the construction of a nuclear power plant. Activists rallied, campaigned, negotiated, renegotiated, and ironically, made demands on the state to itself keep to the law and due process particularly with regards to the constitutional right of democratic dissent, and the need for transparency, accountability and public consultation with the nuclear authorities. They aspired to work through the state rather than against it, knowing full well that any suggestion of anti-state violence as was associated with the Naxalite or Maoist groups in north east India, was to invite the postcolonial state's wrath which could end in the death of people, if not the movement itself. Even though the people's movement against the nuclear power plant has now subsided, not least due to the draconian measures adopted by the nuclear state, we can ensure that the tracts of 
history do not lose sight of their remarkable tenacity, courage and feats to ensure India remains true to its claim as the world's largest democracy.

\section{Acknowledgements}

My sincere gratitude to all my interlocutors in India during the time of my year-long fieldwork in the region in 2006 and periodic visits up until 2018. The early of part of the research was funded by the Economic and Social Research Council (20062008).

\section{References}

Abraham, Itty (1998) The Making of the Indian Atomic Bomb, London: Zed Books.

Agarwal, Vidhi (2012) 'Privacy and data protection laws in India, International Journal of Liability and Scientific Enquiry, 5(3/4): 205-212.

Ajithra, A.K., B. Venkatraman, M.T. Jose, S. Chandrasekar and G. Shanthi (2017) 'Assessment of Natural Radioactivity and Associated Radiation Indices in Soil Samples from the High Background Radiation Area, Kanyakumari district, Tamil Nadu, India', Radiation Protection and Environment 40(1): 27-33.

Appadurai, Arjun (2001) 'Deep Democracy: Urban Governmentality and the Horizon of Politics', Environment and Urbanization, 13(2): 23-43.

Bhawna, Ms. (2016) 'Nuclear Energy, Development and Indian Democracy: The Study of AntiNuclear Movement in Koodankulam', International Research Journal of Management Sociology and Humanity, 7(6):219-229, 
Bidwai, Praful and Achin Vanaik (1999) South Asia on a Short Fuse: Nuclear Politics and the Future of Global Disarmament, New Delhi: Oxford University Press.

Bidwai, Praful (2011) 'People vs Nuclear Power in Jaitapur, Maharashtra,' Economic and Political Weekly, XLVI (8): 10-14.

Brosius, Christiane (2010) India's Middle Class: New Forms of Urban Leisure, Consumption and Prosperity. New Delhi: Routledge.

Dunlap, Alexander (2019) 'Agro sí, mina NO!' The Tía Maria Copper Mine, State Terrorism and Social War by Every Means in the Tambo Valley, Peru'. Political Geography, 71.

Edelman, Marc (2001) Social Movements: Changing Paradigms and Forms of Politics', Annual Review of Anthropology, 30: 285-317.

Flam, Helena (1994) 'A Theoretical Framework for the Study of Encounters between States and Anti-Nuclear Movements' in States and Antinuclear Movements, ed. Helena Flam, Edinburgh: Edinburgh University Press.

Foucault, Michel (2010) The Birth of Biopolitics: Lectures at the Collège de France, 1978--1979 (Lectures at the College de France), London: Picador.

Futrell, Robert and Barbara G. Brents (2003) 'Protest as Terrorism?: The Potential for Violent Anti-Nuclear Activism', American Behavioral Scientist, 46(6):745-765.

Gusterson, Hugh (2004) People of the Bomb: Portraits of America's Nuclear Complex, Minneapolis: University of Minnesota Press. 
Hansen, Thomas Blom (2001) 'Governance and State Mythologies in Mumbai', in States of Imagination: Ethnographic Explorations of the Postcolonial State, eds Thomas Blom Hansen and Finn Stepputat, Durham: Duke University Press.

Hardiman David (2003) Gandhi: In his Time and Ours. New Delhi: Permanent Black.

Jungk, Robert (1979) The Nuclear State, transl, Eric Mosbacher. London: John Calder.

Kaur, Raminder (2012) 'Nuclear Power vs People Power'. Bulletin of the Atomic Scientists https://thebulletin.org/2012/07/nuclear-power-vs-people-power/

Kaur, Raminder (2013) 'Sovereignty without Hegemony: The Nuclear State, and a 'Secret Public Hearing' in India'. Theory, Culture and Society 30(3): 3-28.

Kaur, Raminder (2019a) 'The Digitalia of Everyday Life: Multi-Situated Anthropology of a Virtual Letter by a 'Foreign Hand'. HAU: Journal of Ethnographic Theory, forthcoming.

Kaur, Raminder (2019b) Kudankulam: A Story of an Indian Nuclear Power Plant. New Delhi: Oxford University Press.

Kaur, Raminder (2020) 'Nuclear Necropower'. Political Geography, Special Issue edited by Judith Verweijen and Alexander Dunlap, forthcoming.

Kuletz, Valerie L. (1998) The Tainted Desert: Environmental Ruin in the American West, Hove: Psychology Press.

Laclau, Ernesto (2005) On Populist Reason, London: Verso.

Masco, Joseph (2006) The Nuclear Borderlands: The Manhattan Project in PostCold War New Mexico, Princeton: Princeton University Press. 
Masco, Joseph (2014) The Theatre of Operations: National Security Affect from the Cold War to the War on Terror. Durham: Duke University Press.

Mazzarella, William (2005) Indian Middle Class. http://www.soas.ac.uk/ssai/keywords/

Nilsen, Alf Gunvald (2012) Dispossession and Resistance in India: The River and the Rage, New Delhi: Routledge.

Padmanabhan, V.T., R. Ramesh, V. Pugazhendi, K. Sahadevan, Raminder Kaur, Christopher Busby, M. Sabir and Joseph Makkolil (2013) 'Counterfeit/Obsolete Equipment and Nuclear Safety Issues of VVER-1000 Reactors at Kudankulam, India', Nuclear and Atomic Physics, http://vixra.org/abs/1306.0062

Rakshit, Nirmalendu Bikash (1999) 'Right to Constitutional Remedy: Significance of Article 32', Economic and Political Weekly, 34(34/35): 2379-2381.

Ramana, M.V. and Divya Badami Rao (2008) 'Violating Letter and Spirit: Environmental Clearances for Koodankulam Reactors', Economic and Political Weekly, 2008, 14-18.

Ramana, M.V. (2013) The Power of Promise: Examining Nuclear Energy in India, New Delhi: Penguin Books.

Ruparelia, Sanjay (2013) 'India's New Rights Agenda: Genesis, Promises, Risks', Pacific Affairs, 86: 569-90, p.569.

Senthalir, S. (2012) 'Violence against the Non-Violent Struggle of Koodankulam', Economic and Political Weekly, 47(39): 13-15.

Schmitt, Carl (1985 [1927]) Political Theology: Four Chapters on the Concept of Sovereignty, trans. Schwab G. Chicago: University of Chicago Press. 
Srikant, Patibandla (2009) Koodankulam Anti-Nuclear Movement: A Struggle for Alternative Development? Working Paper 232, Bangalore: Institute for Social and Economic Change.

Udayakumar, S.P. ed. (2004) The Koodankulam Handbook, Nagercoil: Transcend South Asia.

Vaid, Minnie (2016) The Ant in the Ear of an Elephant, New Delhi: Rajpal and Sons.

Varma, Pavan (1998) The Great Indian Middle Class. New Delhi: Viking.

Weber, Max (1978) "Charisma and Its Transformation," in Economy and Society: An Outline of Interpretative Sociology, Berkeley: University of California Press.

Weber, Max (2015) 'Politics as a Vocation', in Weber's Rationalism and Modern Society, translated and edited by Tony Waters and Dagmar Waters. New York: Palgrave Books

1 'Kudankalum women from prison: Tell everyone we are still here!' October 16, 2012, Sundari, Xavieamma and Selvi in conversation with Anitha.S on 12.09.2012 at Trichy Women's Prison. http://www.dianuke.org/kudankalum-women-from-prison-telleveryone-we-are-still-here/ Accessed November 10, 2018.

2 Amnesty International Report 2006: The State of the World's Human Rights, Oxford: Alden Press, p.38. 
${ }^{3}$ Richard Wood (2017) 'The World's 7 Largest Democracies - Where do America and India Fit in?', HTC https://www.hitc.com/en-gb/2017/10/20/the-worlds-7-largestdemocracies-where-do-america-and-india-fit/

${ }^{4}$ Both transnational and multinational companies operate in multiple countries but the latter has a centralized management system in one of these countries. The latter include domestic companies such as Tata, Reliance Infrastructure Limited and Larsen and Toubro who have since 2016, 'poached' NPCIL employees for their companies. P. Sudhakar (2006) 'Private Sector Giants 'Poach' NPCIL personnel', The Hindu, November 20, p.3.

${ }^{5}$ On the Indian middle class, see Brosius (2010), Mazzarella (2005) and Varma 1998).

${ }^{6}$ The term state is shorthand for a complex of organisational structures, personnel, discourses and practices. In Michel Foucault's words as an outcome of a quadrillage of performative processes, 'The state is at once that which exists, but which does not yet exist enough' (2010: 4).

${ }^{7}$ VVER or WWER refers to pressurised water reactor designs and is from the Russian Vodo-Vodyanoi Energetichesky Reaktor; translated as Water-Water Power Reactor.

8 Sharma, Anitha (2012) 'Call for A Women's Support Group in Kerala for Koodankulam Struggle', May 12, DiaNuke, http://www.dianuke.org/call-for-awomens-support-group-in-kerala-for-koodankulam-struggle/ Accessed January 10, 2019.

9 http://www.mail-archive.com/greenyouth@googlegroups.com/msg08208.html. Accessed 8 October 2009. See also Valerie L. Kuletz who refers to it as 'nuclear 
colonialism' (1998: xviii) and Joseph Masco on the 'radioactive colonization' (2006: 101) of the lands of indigenous Pueblo communities in New Mexico.

10 'Why the Kudankulam Nuclear Power Project near Kanyakumari - A few Objections' leaflet (2002), Conservation of Nature Trust, Nagercoil.

${ }^{11}$ S L Goyal, (2002) Court master c/o The Chief Justice, Mr Justice RP Sethi and Mr Justice Arijit Pasayat, writ petition (civil) no 286/2002.

12 The equivalent exchange rate for US dollars at the time would be about 30 rupees per dollar.

${ }^{13}$ Other perspectives on the nuclear power plants including a series of accidents and oversights are provided in Udayakumar (2004).

${ }^{14}$ Central Information Commission Decision No. CIC/SG/A/2012/000544/18674

Appeal No. CIC/SG/A/2012/000544

http://humanrightsinitiative.org/programs/ai/rti/india/national/2012/email_alearts/May/ 02/CIC-KKNP-Site\&SafetyReportscase-order-Apr12.pdf Accessed January 13, 2019. ${ }^{15}$ lbid.

${ }^{16}$ Ibid

17 https://www.dianuke.org/koodankulam-site-evaluation-report-an-analysis-bypmane/ Accessed January 13, 2019.

${ }^{18} \mathrm{Dr} \mathrm{R}$ Ramesh, Dr V Pugazhendi and VT Padmanabhan , 'Safety Issues Of Koodankulam Nuclear Power Plant', 25 March, 2012, Countercurrents

http://www.countercurrents.org/padmanabhan250312.htm Accessed November 10, 2018.

19 https://www.dianuke.org/koodankulam-site-evaluation-report-an-analysis-bypmane/ Accessed November 10, 2018. 
${ }^{20}$ On the interpretation of environmental laws in USA, see Masco (2006: 114-5) and Gusterson (2004: 206-220).

${ }^{21}$ Ponni (2012) 'Kudankulam: A brief history and a recent update', March 21, Kafila, https://kafila.org/2012/03/21/kudankulam-a-brief-history-and-a-recent-update/ Accessed November 10, 2018.

22 Ibid.

${ }^{23}$ S.P. Udayakumar (2012) 'Koodankulam: The Silent And Telling Emergency In India', June 27, http://www.countercurrents.org/udayakumar270612.htm Accessed November 10, 2018

24 'After the Mayhem', September 11, 2012, compiled by Anitha S., Countercurrents, http://www.countercurrents.org/kebinston120912.htm Accessed November 10, 2018. 25 'Kejriwal joins Koodankulam Anti-nuke Stir, High Drama on Site', India Today, 12 September 2012 https://www.indiatoday.in/india/story/kejriwal-joins-koodankulam-anti-nuke-stir-high-dramaon-site-115899-2012-09-12 Accessed 10 January 2019.

${ }^{26}$ Arun Janardhanan (2012) '8,856 "Enemies of State”: An Entire Village in Tamil Nadu lives under Shadow', September 12, http://indianexpress.com/article/india/india-news-india/kudankulam-nuclear-plantprotest-sedition-supreme-court-of-india-section-124a-3024655/ Accessed January 10, 2017.

27 http://indiaenvironmentportal.org.in/reports-documents/report-jury-public-hearingkudankalum-and-state-suppression-democratic-rights Accessed January 10, 2013. ${ }^{28}$ Ibid.

${ }^{29}$ Such capricious measures bring to mind the controversial case of Iftikhar Gilani, a Jammu-based journalist who was imprisoned without bail under the Official Secrets Act in 2002. As Siddharth Varadarajan asserts: 'His crime - possessing out-of-date 
information on Indian troop deployments in "Indian-held Kashmir" culled from a widely-circulated monograph published by a Pakistani research institute'. The case fell apart due to the inconsistencies of fabricated reports by the Union Ministry of Home Affairs (MHA), Delhi Police and Intelligence Bureau (IB). Siddharth Varadarajan (2005) 'My Foreword to Iftikhar Gilani's My Days in Prison', February 1 http://svaradarajan.blogspot.com/2005/02/my-foreword-to-iftikhar-gilanis-my.html Accessed January 12, 2019.

${ }^{30}$ S.P. Udayakumar (2012) 'Kudankalum: The Silent And Telling Emergency In India', $\quad$ Countercurrents, $\quad$ June 27, http://www.countercurrents.org/udayakumar270612.htm Accessed November 10, 2018.

31 'Kudankalum Update: Arrests of Peaceful Protesters Under the Sedition Law in Tamil Nadu, India', March 20, 2012, https://indian2006.wordpress.com/2012/03/20/kudankalum-update-arrests-ofpeaceful-protesters-under-the-sedition-law-in-tamil-nadu-india/ Accessed November 10, 2018.

32 'Kudankalum: Letter to CM about Attack on School', Dianuke, April 30, 2012 http://www.dianuke.org/kudankalum-letter-to-cm-about-attack-on-school/ Accessed November 10, 2018.

33 'Kudankulam Protests, Church and Western NGOs - A Citizen's Probe' (2012) http://ariseasia.blogspot.co.uk/2012/02/Kudankulam-protests-church-andwestern.html Accessed: 10 November, 2016. 
34 'FCRA Licenses of 20,000 NGOs Cancelled', The Times of India, December 27, 2016 http://timesofindia.indiatimes.com/india/fcra-licences-of-20000-ngoscancelled/articleshow/56203438.cms Accessed: October 12, 2017.

${ }^{35}$ Rakesh Dubbudu (2012) 'Massive FCRA Cancellation is not a new thing. 4138 NGOs lost their FCRA licenses in 2012', Factly, 29 April https://factly.in/massive-fcra-cancellation-is-not-a-new-thing-4138-ngos-lost-theirfcra-licenses-in-2012/ Accessed: 12 January 2019.

${ }^{36}$ Bharti Jain (2016) 'MHA Goofs up, Renews Greenpeace's FCRA License,' The Times of India, December 14 http://timesofindia.indiatimes.com/india/MHA-goofs-uprenews-Greenpeaces-FCRA-licence/articleshow/55970187.cms Accessed: October 12, 2017.

37 'India Cracks down on Greenpeace and Foreign NGOs', Aljazeera, 27 May, 2015 http://www.aljazeera.com/news/2015/05/india-cracks-greenpeace-foreign-ngo150526102622208.html Accessed: October 12, 2017.

38 'FCRA as a Tool of Repression: Greenpeace India Signs Civil Society Statement in Solidarity with those Denied Registration', Greenpeace India, December 14, 2016 http://www.greenpeace.org/india/en/news/Feature-Stories/FCRA-as-a-tool-ofrepression-Greenpeace-India-signs-civil-society-statement-in-solidarity-with-thosedenied-registration/ Accessed: October 12, 2017.

39 'Republic Channel Exposed 'Activism for a Price' in Anti-nuclear Protests, Funded by the Church. S. P. Udayakumar was in the Sting. What is your Take?' Quora, https://www.quora.com/Republic-Channel-exposed-Activism-for-a-price-in-antinuclear-protests-funded-by-the-church-S-P-Udayakumar-was-in-the-sting-What-isyour-take Accessed November 10, 2018. 